\title{
DEVELOPING ENGLISH INSTRUCTIONAL MATERIALS FOR STUDENTS OFCOMPUTER SCIENCE DEPARTMENT (A NEEDS ANALYSIS)
}

\author{
Fransisca Endang Lestariningsih ${ }^{1}$, Arida Susyetina ${ }^{2}$, Lucia Dwi Krisnawati ${ }^{3}$ \\ ${ }^{1}$ Duta Wacana Christian University, Indonesia \\ 1endang@staff.ukdw.ac.id \\ ${ }^{2}$ Duta Wacana Christian University, Indonesia \\ 2arida@staff.ukdw.ac.id \\ ${ }^{3}$ Duta Wacana Christian University, Indonesia \\ ${ }^{3}$ krisna@staff.ukdw.ac.id
}

\begin{abstract}
English is one of compulsory subjects at the computer science department in a higher education. Since English is not a field of study at the computer science, it is taught as an ESP (English for Specific Purposes). The fact that English is part of the curriculum at the computer science department makes it challenging for both the teachers and the students. The majority of the students will always deal with motivation, whereas teachers face a great challenge in designing an appropriate instructional material that gives short-term and long-term effects to the students. Besides, there are two types of teachers who teach English for computer science students, English teachers who have English education background and English teachers who do not own degrees in English education. These two types of teachers experience their own strengths and weaknesses in designing English instructional materials. This research, therefore, will combine the strengths of the teachers in the development of English instructional materials for computer science students that will have short-term and long-term impacts to the students. This research is applying an action research which is divided into some cycles of planning, action, observation, and reflection. The participants are three English teachers and two classes of computer science students.
\end{abstract}

Keywords: ESP, EAP, instructional materials

\section{INTRODUCTION}

University students in general have started studying English since they were in Junior High School, approximately six years before they go to college. However, this does not goes in line with the development of their English proficiency, especially when their study requires good English skills that would equip them in reading academic references written in English. Yet, English teachers who teach "English for Specific Purposes" (ESP) need to be more creative in advancing their students' level of English proficiency.

Low English proficiency has proven to be an obstacle and crucial issue for university graduates in the professional life. As written in the report of the "World Bank Human Development Department, East Asia and Pacific Region" in "Trends in Skills Demand, Gaps, and Supply in Indonesia", that:

The widest gaps across professional profiles are for English and computer skills followed by thinking and behavioral skills. Gaps in computer and English skills are likely to be more felt in export and technologically oriented sectors and sub-sectors (p. xiv)

Furthermore, the document claims that (even though) there is a big gap in creativity, computer literacy, and other technical skills, the biggest gap is on English proficiency. 
While English may not be considered that relevant it is however perceived as the most serious gap (and by younger and older workers alike), matching employers' perceptions. (p. xv)

One of the most important things in improving students' English skills is by compiling learning materials that suit their study objectives such as completing their study (short term goal) and to be globally competent (long term goals).

Based on the given background, the study aims 1) to find out the needs of English proficiency of the Informatics Engineering students, and 2) to develop appropriate learning materials that suit the Informatics Engineering students' study objectives both for their short and long term goals.

By compiling the learning materials of English for Informatics (Bahasa Inggris Informatika-BII) based on the need analysis, it is hoped that this module could equip and aid the students, the teachers of "English for Informatics", the teachers of Informatics Engineering Department, and support its curriculum development. Thus, it could benefits students in advancing their level of English proficiency to achieve their study objectives and the teachers of "English for Informatics" in conducting the authentic learning activities. As for the the teachers of Informatics Engineering Department and the department's curriculum development, this study would corroborate other subjects or courses that exposes English both in the spoken and written form.

\section{LITERATURE REVIEW}

\subsection{English for Specific Purposes}

English for Specific Purposes (ESP) arose as a term in the 1960's as it became increasingly aware that general English courses frequently did not meet learner or employers needs. The demand for ESP is growing rapidly, particularly in a country where English serves as a Foreign Language (EFL) such as Indonesia, where English is mainly used for instrumental purposes. People in Indonesia learn English in order to fulfill the school curriculum requirement, to pass standardized English proficiency tests (TOEFL, IELTS), or to obtain promotion or professional development at work. In the higher education, however, the ESP terminology is used overlapping with English for Academic Purposes (EAP). EAP refers to the language and associated practices that people need in order to undertake study or work in English medium higher education. Therefore, the objective of an EAP course is to help these people learn some of the linguistic and cultural - mainly institutional and disciplinary - practices involved in studying or working through the medium of English (Gillet, 2011). Moreover Gillet argues that "EAP is often considered to be a branch of ELT, although not all EAP teachers have come through the ELT route". It is a type of ESP in that the teaching content is explicitly matched to the language, practices and study needs of the learners. The central role of the EAP teacher or course designer is to find out what the learners need, what they have to do in their academic work or courses, and help them to do this better in the time available.

The above explanation about ESP is also acknowledged by other scholars, such as Paltridge \& Starfield (2013) who argue that ESP refers to the teaching and learning of English either as a second or foreign language in which the goal of the learners is to use English in a particular domain. A key feature of an ESP course is, therefore, the orientation of the content and the aims of a course to the specific needs of the learners. Thus ESP courses focus on the language, genres, and skills that are appropriate to the specific activities that are needed by the learners to carry 
out in English. ESP students are usually adult learners with specific needs and often homogeneous groups in terms of learning goals, although it does not guarantee that their proficiency in the target language is the same. Since ESP is intended for special people who need special language skills and genres, the main issues in the developing ESP teaching are how to identify learner needs (needs analysis), the nature of the genres that the learners need to be able to produce as well as participate in, and how teachers can know that the learners have been able to do this successfully, and if not, what the teachers can do to help them do this.

Two key features are, therefore, becoming the concerns of designing ESP materials, needs analysis and the teaching backgrounds of the teachers. These two concerns will be used as the foundations to design appropriate English teaching materials for students of computer science department in a higher education.

\subsection{Language teaching concepts}

Language teaching experts and practitioners have defined the concept of teaching in many ways. One of them is proposed by Brown (2007: 7) who argues that "teaching is guiding and facilitating learning, enabling the learner to learn, setting the conditions for learning". In line with the above definition of teaching Weinbaum, Allen, \& Blythe (2004: 16) also state that teaching is an activity to assist and to guide the students to be able to change and increase their skills, behavior, dreams, rewards, and knowledge. Teaching is a process to help the students to construct their knowledge using conceptual frameworks. Another similar definition is given by Raka Joni (1993) who claims that teaching is awakening and assisting the students to be able to learn.

The above definitions obviously indicate that teachers are required to be able to be the agents to change the behavior of their students in learning. However, the main subject in teaching is the students, themselves. The task of the teachers is to design a learning situation that can facilitate the students to be able to deal with various obstacles that need their skills in identifying and manipulating critical changes in order to achieve their goals in learning. The role of the teachers is not merely delivering information, but motivating and guiding their students, as well as becoming the provider of teaching for their students.

Nurkamto (2004), after reviewing some definitions of teaching, argues that there are two implications in teaching. First is the role of a teacher as a teacher, whose job is to help the students to learn. The assistance could be in the form of motivating and guiding the students. The teacher is also expected to be able to provide some learning tools and aids as the facilities of learning. Giving the students motivation could be through making them realize about their intrinsic and extrinsic motivation. Guiding the student, which can be in the form of explaining the goals of the subject, the nature of the tasks, and the strategies used to do the tasks, means helping them to find the fine ways in learning. Providing the facilities to learn indicates that the teacher should be able to facilitate the learning, to make it easy to learn. This can be broadly interpreted as designing and creating good condition in order to learn and providing learning facilities.

The second implication concerns with who the most responsible persons in the learning activities is. Nurkamto (ibid), moreover, explains that the responsibility towards the process of learning should go to the students. Students become the subject of autonomous learners. Furthermore, Nurkamto presents the research result conducted by Cotteral \& Crabbe (1992) towards the language learners. It shows that an autonomous learner is a learner who 1) plans and organizes his/her own experiences in studying, 2) knows the field of studies, 30 monitors own progress in 
studying, 4) finding an opportunities to do the exercises, 5) is enthusiastic about a language and learning it, and 6) is confident in using the language and finds help if necessary.

The above discussions lead to a conclusion that as educators, teachers should be able to be the agent of changes of the students' behaviors. However, what should be kpet in mind is that the main agent of the changes is not the teachers, but the students. Any tasks given to them should be well-designed in order to facilitate the students to face the difficulties found and to be able to deal with them. Thus, the main responsibility of a teacher is not only to provide information, but also to motivate and guide the students, as well as to be the teaching resource for the students.

2.3. Review of Related Research

This part discusses two studies conducted in two dissertations considered relevant to this research. They are dissertations by Imroatus Solikhah, from Universitas Sebelas Maret, titled Buku Teks bahasa Inggris Akademik Berbasis Kompetensi untuk Mahasiswa Jurusan Non-Bahasa Inggris (Competency-Based Academic English Textbooks for the Non-English Department Students), and Ismail Petrus (UPI) which talked about English Language Teaching in Higher Education: an English Course Design at a State University. The three works are chosen because the findings could be used as the comparison and sources.

Imroatus Solikhah's dissertation is reviewed because she designed a book for non-English department students, which is relevant to this study. She also employed Research and Development research design, which is also relevant to this study. Her findings revealed that among the four universities studied (UNS, UNY, UNDIP, and UNSOED), only one had qualified and standardized textbook. She, then, concluded that the need of English textbook among non-English department students was important. Based on the findings, she developed a prototype of a textbook validated by expert judgment and experiment. The designed book was then disseminated by printing and selling it through some bookstores. The theoretical implication of the research findings is that the EAP topic should be added in the ELT theory, such as EAP practices and academic literacy in Indonesia, and the Delta Cambridge Syllabus can be considered in the curriculum design.

The second review is from the dissertation of Ismail Petrus that discusses an English course design in higher education. His findings reveal that the present English course in the time of doing the research was of general English in nature, not ESP. There was no attempt to discover the needs of the learners, since there was no need analysis conducted prior to the design of the English course. He argued that the prospective English course was an EAP course, specifically EGAP (English for General Academic Purposes).

2.4.Model of Development

For the ESP teachers or course designers, the central role is to find out what the learners need, what they have to do in their academic work or courses, and help them to do this better in the time available. Below is the adaptation of Bell, 1981 (in Gillet, 2012) that provides a useful model to do the role. This study is fulfilling the first two steps of the above model, analyze the target needs and analyze the students' performance. 


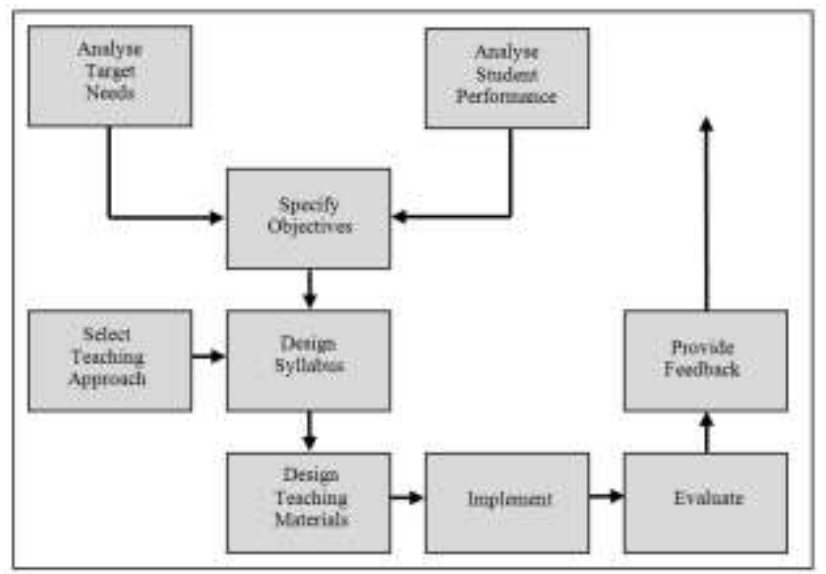

\section{METHODS}

This study aims at finding the needs for the development of English instructional materials for students of computer science departments. Needs analysis is considered as a very important step in this study. The needs analysis includes problem identification and diagnosis. Needs analysis, according to Brown (1995: 36) is "the systematic collection and analysis of all subjective and objective information necessary to define and validate defensible curriculum purposes that satisfy the language learning requirements of students within the context of particular institutions that influence the learning and teaching situation".

This study, thus, adopted action research/AR as the needs analysis. Four considerations are applied in adopting AR in this study, as proposed by Burns (2009). They are 1) AR wants to explore the best possible ways of setting up activities, 2) AR wants to know more about what works well in certain situation, 3) AR uses a much more flexible and open-ended approach, selecting, and changing the methods as needed as new insights emerge, and 4) AR is interested in understanding personal knowledge for developing theories.

AR comprises of four steps: Plan, Action, Observe, and Reflect which is divided into some related cycles. The following is figure of how AR works proposed by Kemmis and McTaggart (2014).

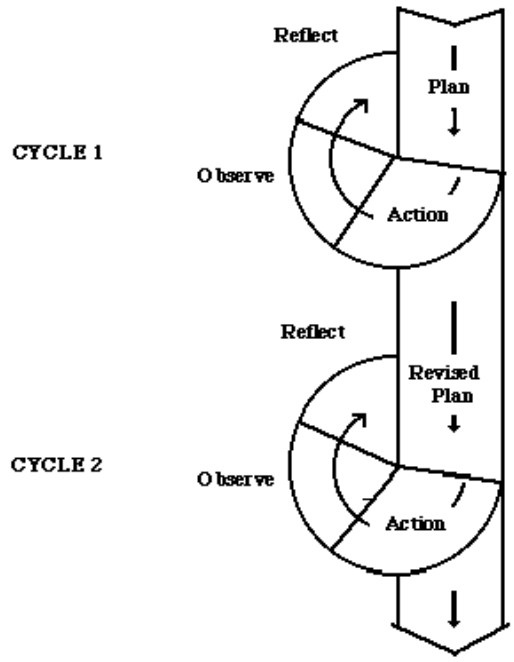

Among the different kinds of AR, critical participatory action research (CPAR) is selected as the research design to develop and to improve the materials to get the most appropriate one as Kemmis and McTaggart (2014) argued that "one of the most important things that happens in critical participatory action research is simply 
that participants get together and talk about their work and lives". The participants are supposed to explore if things are going as what they expect or the other way around.

In line with Kemmis and McTaggart, Carr (2006) stated that "Critical participatory action research) brings people together to reflect and act on their own social and educational practices in disciplined ways to make their practices, the way they understand their practices, and the conditions under which they practice more rational, more sustainable, and more just."

The main subjects of this needs analysis were three teachers of English for Computer Science subjects (BII) and the students of two classes of BII (population) at Duta Wacana Christian University, while the additional subjects were the Head of the Computer Science Department and the users of the graduates of computer science department. The teachers' backgrounds are two who have English education background and one who does not own degrees in English education. These two types of teachers experience their own strengths and weaknesses in designing English instructional materials. This research, therefore, will combine the strengths of the teachers in the development of English instructional materials for computer science students that will have short-term and long-term impacts to the students.

In analyzing the needs of the students of computer science department, this study employed three cycles of planning, acting, observing and reflecting. The needs analysis was to analyze the target needs and analyze the students' performance. Questionnaire, interview and observation were conducted to find out the short-term, middle-term and long-term needs of the computer science students.

\section{FINDINGS AND DISCUSSION}

This study has involved two English teachers who own master degrees in English education and one teacher from computer science field. Two classes of English for Computer Science subjects were also involved. Before conducted the cycles in AR, some interviews were conducted and some questionnaires were distributed to the students. The result of the interviews was as follows.

\begin{tabular}{|l|l|}
\hline \multicolumn{1}{|c|}{ Teacher's Teaching Emphasis } & \multicolumn{1}{c|}{ Customers' needs (Companies, Individuals) } \\
\hline 1. Reading & 1. Speaking \\
\hline 2. Writing & 2. Writing \\
\hline 3. Speaking & \\
\hline
\end{tabular}

From the table, it can be seen that there was a mismatch between the needs of students in the eye of the teachers and the needs of the users (companies and individuals) who employ the graduates of Computer Science Department. Based on the teachers, students need reading skills, followed by writing and speaking; while according to the users, they need employees who have speaking and writing English skills. This different needs were also seen from the students' point of views, as depicted in the following pie chart $(n=40)$. 


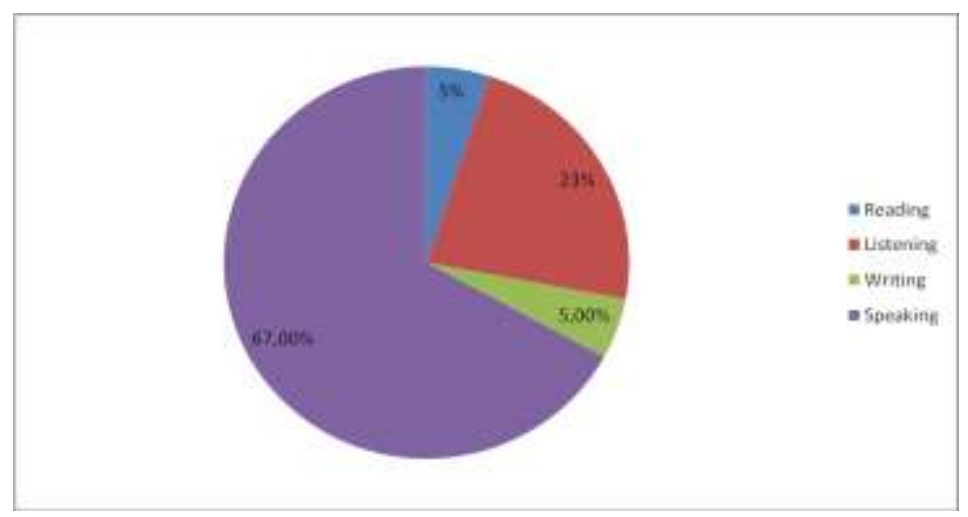

The above chart shows that computer science students' needs of speaking skill, followed by listening outweigh the other two skills. The assumption of their need, however, is in line with the need of the users.

The questionnaire also asked the students to rate their difficulties in learning English. More than $50 \%$ of them exclaimed that the most challenging skills were listening (35\%) and speaking (32.5\%). The following pie chart illustrates this challenge.

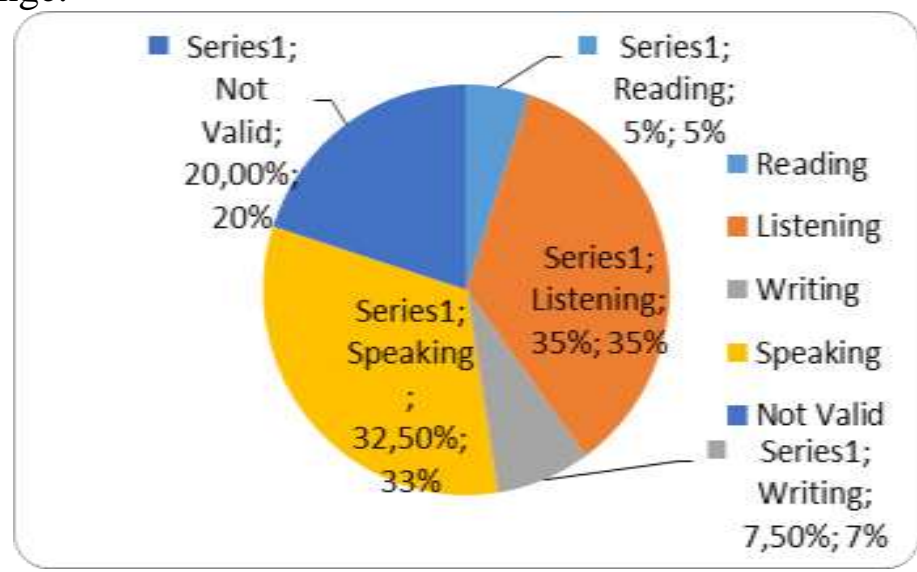

Considering their own justification about their English skill, most of them said that their skill was average (55\%); only few who acknowledged that their English was below average and very good with the percentage of $22.5 \%$ and $20 \%$ respectively.

Asking the students about their macro-skills is not sufficient to see whether they really understand their achievements. Therefore the questionnaire also aims at finding out their knowledge of the micro-skills of English. In the reading microskills, the questions were about whether or not the students experienced using some skills such as predicting, scanning, skimming, interpreting and summarizing. For the first three micro-skills, only almost half of them answered they never used them; while interpreting and summarizing were two micro-skills that seem unfamiliar to the students since they said that, more than $70 \%$, they never used the skills in understanding reading text. In terms of their exposure of reading English texts, $52.5 \%$ stated that they were quite frequent in it; while the rest admitted that they were almost never applied their reading skills.

The same questions go to other macro skills: listening, speaking and writing. The data collected for listening and writing's exposure were almost the same as that for reading. Nevertheless, the condition was not applicable to speaking. Almost every student confessed that it was almost uncommon for them to speak in English. This is shown by the very high percentage who answered they rarely used (79\%) 
and almost never used (12.5) that outnumbered the students who frequently used English speaking skill in their life.

\section{CONCLUSION}

Based on the above findings, the writers draw a conclusion that materials prepared and given to computer science students should cover all macro-skills in English with the emphasis on reading skill, to fulfill the short-term need of the students which is being able to comprehend English text better, and speaking, for the sake of their long-term need, that is fulfilling the need of the users. Even though the other two skills, listening and writing, are least important, according to the survey, they should also be covered in designing the materials. The former will help the students in their long-term need, to listen to the clients, for instance; while the later is important in order that they can have exposure to be able to write coherently and cohesively for their final writing (thesis writing).

\section{REFERENCES}

Basturkmen, H. (2010). Developing courses for English for Specific Purposes. New York: Palgrave Macmillan

Brown, H. D. (2007). Principles of language learning and teaching. Fifth Edition. New York: Pearson.

Burns, A. (2010). Doing action research in English Language Teaching. Oxon: Routledge.

Cowan, M.A. (2008). Beyond single interest: Broad-based organizing as a vehicle for promoting adult literacy. Review of Adult Learning and Literacy. Volume 6. New Jersey: Lawrence Erlbaum Associates, Inc.

Fatihi, A.R. (2003). The role of need analysis in ESL Program design. South Asian Language Review. 13 (1 \& 2). 39-59. Retrieved from http://ssalr.net?documents/fatihi.pdf in September 2015.

Gillett, A. J. (2011). What is EAP? Retrieved from http://www.uefap.com/bgnd/ on May 2015.

Hamp-Lyons, L. (2011). English for Academic Purposes. Handbook of Research in Second Language Teaching and Learning. Volume II. In E. Hinke (Ed.). New York: Rotledge.

Hutchinson, T. \& Waters, A. (1991). English for Specisif Purposes: a learning centered approach. New York: Cambridge University Press.

Hyland, K. (2006). English for academic purposes: An advanced resource book. New York: Routledge.

Jordan, R.R. (1997). English for Academic Purposes: a guide and resource books for teachers. Cambridge: Cambridge University Press.

Kemmis, S., McTaggart, R \& Nixon, R. (2014). The action research planner. Singapore: Springer Science.

Knowles, M. (2005). The adult learner. Sixth Edition. Burlington, M.A.: Elsevier Inc.

McKay, S.L. (2012). Principle of teaching English as an international language. Principles and Practices of Teaching English as an International Language. (eds. Lubna Alsagoff, et.el.). New York: Routledge.

Nation, I.S.P \& Macalister J. (2010). Language curriculum design. New York: Routledge.

Richey, R. C. \& Klein, J. D. (2007). Design and Development Research. New Jersey: Lawrence Erlbaum Associates, Inc. 
Richards, J. C. (1998). Beyond training: Perspectives on language teacher education. United Kingdom: Cambridge University Press.

Richards, J.C. \& Rodgers, T.S. (2002). Approach and methods in language teaching. Second Edition. Cambridge : Cambridge University Press.

Richards, J.C. \& Lockhart, C. (2007). Reflective teaching in second language classrooms. New York: Cambridge University Press.

Schutz, N. (2013). How specific is English for Academic Purposes? A look at verbs in business, linguistics and medical research articles. Language \& Computers. 77. 1. 237-257

Stern, H.H., (1991), Fundamental Concepts of Language Teaching. Oxford: Oxford University Press.

Wingate, U. \& Tribble, C. (June 2012). The best of both worlds? Towards an English for Academic Purposes/Academic Literacies writing pedagogy. Studies in Higher Education. 37.4. 481 - 495. http://dx.doi.org/10.1080/03075079.2010.525630 